\title{
Late Holocene palaeohydrological changes in a Sphagnum peat bog from NW Romania based on testate amoebae
}

\author{
Andrei-Cosmin DIACONU ${ }^{*}$, Roxana GRINDEAN ${ }^{1}$, Andrei PANAIT ${ }^{1} \&$ Ioan TANȚĂU ${ }^{1,2^{*}}$
}

\author{
${ }^{1}$ Babeş-Bolyai University, Department of Geology, Kogălniceanu 1, 400084 Cluj-Napoca, Romania \\ ${ }^{2}$ Institute of Biological Research, Republicii 48, 400015 Cluj-Napoca, Romania
}

Received: August 2015; accepted January 2016

Available online 12 January 2016

DOI: http://dx.doi.org/10.5038/1937-8602.60.1.1285

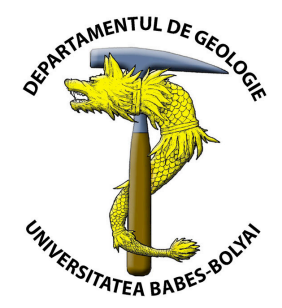

\begin{abstract}
This paper investigates the possibility of reconstructing the palaeohydrological changes in an active Sphagnum peat bog from north-western Romania using testate amoebae fauna and organic matter content determined by loss on ignition (LOI). In total 28 taxa of testate amoebae were identified of which 11 were frequent enough to present a remarkable ecological significance. Based on the relative abundance of these taxa nine zones were identified, crossing from very wet to dry climate conditions. The wet periods identified are characterized by taxa like Centropyxis cassis, Amphitrema flavum and Hyalosphenia papilio, while in the dry periods Difflugia pulex and Nebela militaris thrive. We showed that combining qualitative information regarding hydrological preferences with the quantitative percentage data from the fossil record it is possible to obtain information regarding major surface moisture changes from the peat bog surface. Furthermore we identified a link between distribution of testate amoebae assemblages, organic matter variation and minerogenic material.
\end{abstract}

Keywords: testate amoebae, moisture, organic matter, peat bog, Romania.

\section{INTRODUCTION}

Testate amoebae (Protista) are a group of unicellular organism which often occur in a large variety of moist environments but are most frequent in peat bogs. These are characterized by a test formed through secretions (proteinaceous or pseudochitinous) or agglutination which is susceptible to fossilization.

These organisms were used for palaeoenvironmental reconstruction in peat bogs and lake sediments for over one century (Lindberg, 1899) and their palaeoecological significance is further investigated in more recent studies (Tolonel et al., 1992, 1994; Woodland et al., 1998).

In most of the studies testate amoebae are used as indicators of hydrological changes in peat bogs (moisture and depth to water table) due to their quick response towards these factors (Booth and Zygmunt, 2005; Opravilová and Hájek, 2006; Lamentowicz et al., 2010). Also different aspects of water chemistry have been linked to the variations of testate amoebae communities. $\mathrm{pH}$ is one of the most studied factors of water chemistry that was used in palaeoenvironmental reconstructions (Lamentowicz and Mitchell, 2005; Payne et al., 2006), nevertheless it is a less important indicator than surface moisture and depth to water table (Tolonen et al., 1994; Charman and Warner, 1997).

Data obtained from testate amoebae are usually analyzed using two different ways: qualitative reconstruction using ecological indicator values of taxa and quantitative reconstruction. Both qualitative and quantitative techniques depend on a good knowledge of testate amoebae ecology. The qualitative method is a technique which uses the data in a subjective way in order to induce past conditions, the fossil community reflecting a series of conditions on a descriptive scale from very wet to very dry. The quantitative methods (transfer functions) use the relationship between hydrology or different aspects of the taxa ecology and modern associations in order to reconstruct past hydrological changes but are usually restricted to ombrotrophic peat (Warner and Charman, 1994; Mitchell et al., 2001; Lamentowicz and Mitchell, 2005; Payne et al., 2006; Schnitchen et al., 2006; Charman et al., 2007; Amesbury et al., 2013; Lamarre et al., 2013).

To date, in Romania, despite numerous peat bogs that can be excellent archives for testate amoebae (TA) based reconstruction data on fossil TA is limited to only two records (Schnitchen et al., 2006; Feurdean et al., 2015) although palaeoecological studies are abundant (e.g., Fărcaş et al., 2005; Feurdean et al., 2008, 2013; Tanţău et al., 2011, 2014)

This study is focused on a Sphagnum dominated peat bog from Romania and the main objectives will be: i) analysis of testate amoebae fossil assemblages for qualitative reconstruction of the moisture conditions on the peat surface; ii) loss on ignition analysis (LOI) for the calculation of organic matter and minerogenic material content in sediments; iii) to assess the possible correlation between the qualitative reconstruction of the major wet-dry shifts, the content of organic matter and the minerogenic material input.

\section{STUDY SITE}

The peat bog chosen for this study is situated in NW Romania in Iaz region $\left(47^{\circ} 06^{\prime} \mathrm{N}, 22^{\circ} 39^{\prime} \mathrm{E}, 300 \mathrm{~m}\right.$ altitude) 
(Fig. 1) and it is part of the Nature Reserve "Mlaştina de la Iaz" that covers 10 ha. The surface of the peat bog is about 0.35 ha with the peat deposit reaching a depth of $5.10 \mathrm{~m}$ (Munteanu and Raus, 1984). The region is under the influence of a temperate continental climate with an annual mean precipitation above $700 \mathrm{~mm}$ and an annual mean temperature of $8^{\circ} \mathrm{C}$.

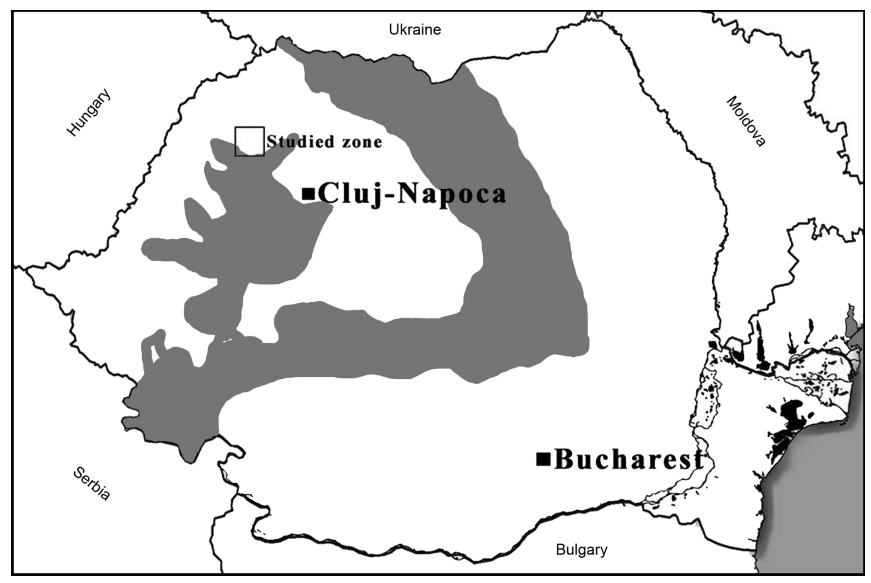

Fig. 1. Location map of the study site.

The wet land part of the reservation is surrounded by dense forest belts that provide protection of the meso-oligotrophic vegetation and is composed of an inner belt dominated by Alnus glutinosa, and an outer forest belt mainly composed of Fagus sylvatica, Quercus petraea and Corylus avellana.

The area was declared nature reservation primarily because of the plant taxa encountered such as Sphagnum amblyphyllum, Sphagnum magellanicum, Sphagnum subsecundum and one of the few carnivore taxon (Drosera rotundifolia) present in Romanian flora.

The data about the study area were extracted from the Management Plan of this nature reserve compiled by the Institute of Biological Research (2012).

\section{MATERIALS AND METHODS}

\section{Coring and chronology}

The coring was performed with a Russian sampler $(60 \mathrm{~cm}$ length and $6 \mathrm{~cm}$ diameter) in September 2012. The drilling depth was $540 \mathrm{~cm}$, however the recovery of fossil testate amoebae was possible only as deep as $365 \mathrm{~cm}$. In the field the cores were preliminary described, placed in half PVC tubes and wrapped in plastic films.

The chronology was established by seven AMS radiocarbon measurements on bulk peat at the Radiocarbon Laboratory in Poznán, Poland (only 4 were used in this study). The ${ }^{14} \mathrm{C}$ measurements were calculated into calendar years BP using INTCAL13 data set of Reimer et al. (2013) with Clam software (Blaauw, 2010). Based on the resulting data an agedepth model was constructed using the midpoints of the $2 \sigma$ calibrated age ranges of the dates (Fig. 2).

\section{Testate amoebae}

Sub-samples of $1 \mathrm{~cm}^{3}$ were collected at $5 \mathrm{~cm}$ intervals along the peat core. The fossils were isolated from the peat using a sieving procedure without any chemical regents (Hendon and Charman, 1997; Charman et al., 2000). The samples were placed in a beaker $(200 \mathrm{ml})$ with distilled water $(100 \mathrm{ml})$.

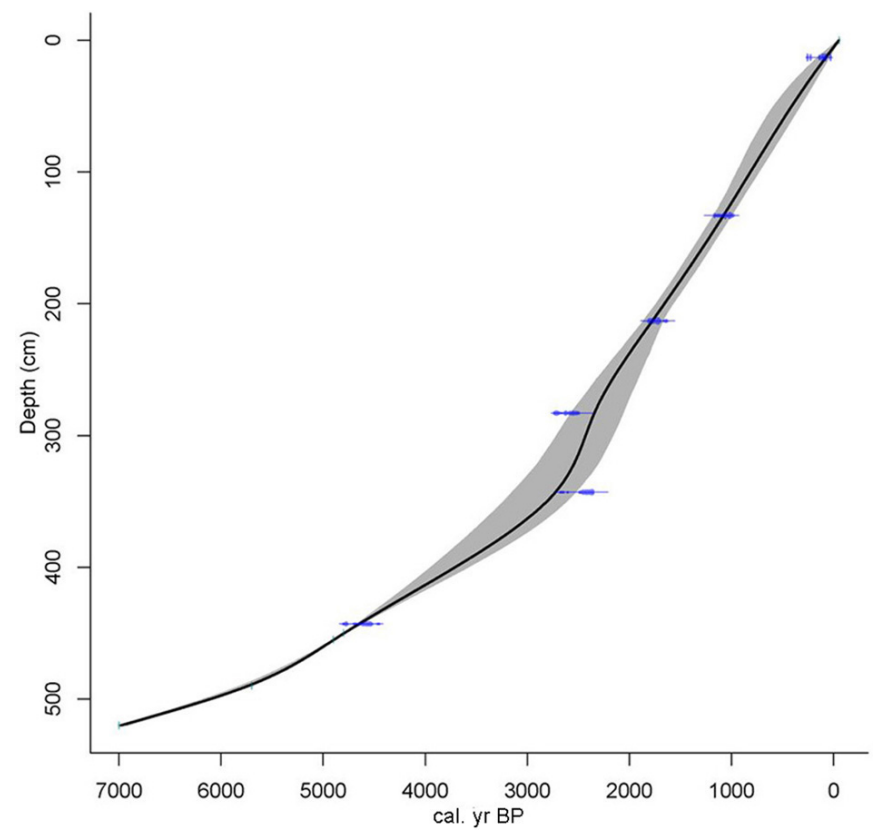

Fig. 2. The age-depth model for Mlaştina de la Iaz (after Grindean et al., 2014).

Lycopodium tablets were added to the samples to estimate the test concentrations (Stockmarr, 1971) and boiled for approximately 10 minutes, stirring occasionally to disaggregate peat and disperse the Lycopodium spores. Distilled water was added to cool off the samples, and the material was washed through $300 \mu \mathrm{m}$ sieve. In this case the $15 \mu \mathrm{m}$ sieve was omitted to avoid the loss of particularly small taxa (Payne, 2009; Wall et al., 2009). After the $300 \mu \mathrm{m}$ sieving the material was placed into $50 \mathrm{ml}$ centrifuge tube and centrifuged at 3000 RPM for 10 minutes. Water was decanted and the residues were transferred into stropped vials with glycerol. Samples were mounted on slides and analyzed under a biological microscope with a 400x magnifier counting up to a minimum of 150 taxa from each sample (Payne and Mitchell, 2009). Taxonomic identification was followed to the highest possible level based on the available literature (Ogden and Hedley, 1980; Charman et al., 2000; Clarke, 2003; Mazei and Tsyganov, 2006).

\section{Loss on ignition}

The organic matter content of the core was estimated using the loss on ignition (LOI) method (Dean, 1974; Heiri et al., 2001). The core was sub-sampled and analyzed at $5 \mathrm{~cm}$ intervals (from the same horizons as the testate samples) and at $2.5 \mathrm{~cm}$ when a higher resolution was needed. The samples were placed in crucibles, weighed and then dried over night at $100^{\circ} \mathrm{C}$ to estimate the water content. LOI is expressed as a percentage of the weight of the samples and illustrates the organic matter $(\mathrm{OM})$ content that burns at $550^{\circ} \mathrm{C}$, the carbonates content (carbonates) that burns at $950^{\circ} \mathrm{C}$ and the remaining matter that represents the minerogenic material.

The data was plotted using the C2 program (Juggins, 2003).

\section{RESULTS}

\section{Lithostratigraphy and chronology}

The peat core recovered from Iaz reached $540 \mathrm{~cm}$ (Grindean et al., 2014) but due to poor preservation of the fossils, the testate amoebae tests could be studied only to the depth of 
$365 \mathrm{~cm}$. The present study will take into consideration only this part. The sequence is composed of peat and clayey peat with different degrees of humification and composition. Carex peat accumulated between 365 and $330 \mathrm{~cm}$, Carex-Sphagnum peat deposited between 330-190 cm and Sphagnum peat forms the last $190 \mathrm{~cm}$ of the sequence. A simplified stratigraphy of the sequence used $(0-365 \mathrm{~cm})$ is given in the left part of the diagrams (Figs. 3-4). The complete description of the sequence and the accumulation rate are discussed in Grindean et al. (2014).
The uncalibrated and calibrated ages of the radiocarbon measurements are presented in Table 1. Because of the poor preservation of the pollen in the bottom part of the sequence and a possible hiatus at around $520 \mathrm{~cm}$ the first radiocarbon date $(8380 \pm 50 \mathrm{BP})$ was ruled out. Therefore, pollen stratigraphic markers from nearby sites were used for assigning the beginning of the peat sedimentation from our sequence to a given age (Grindean et al., 2014). Thus our record starts at about $7000 \mathrm{cal}$ yr BP and the TA analysis at about 3050 cal yr BP.

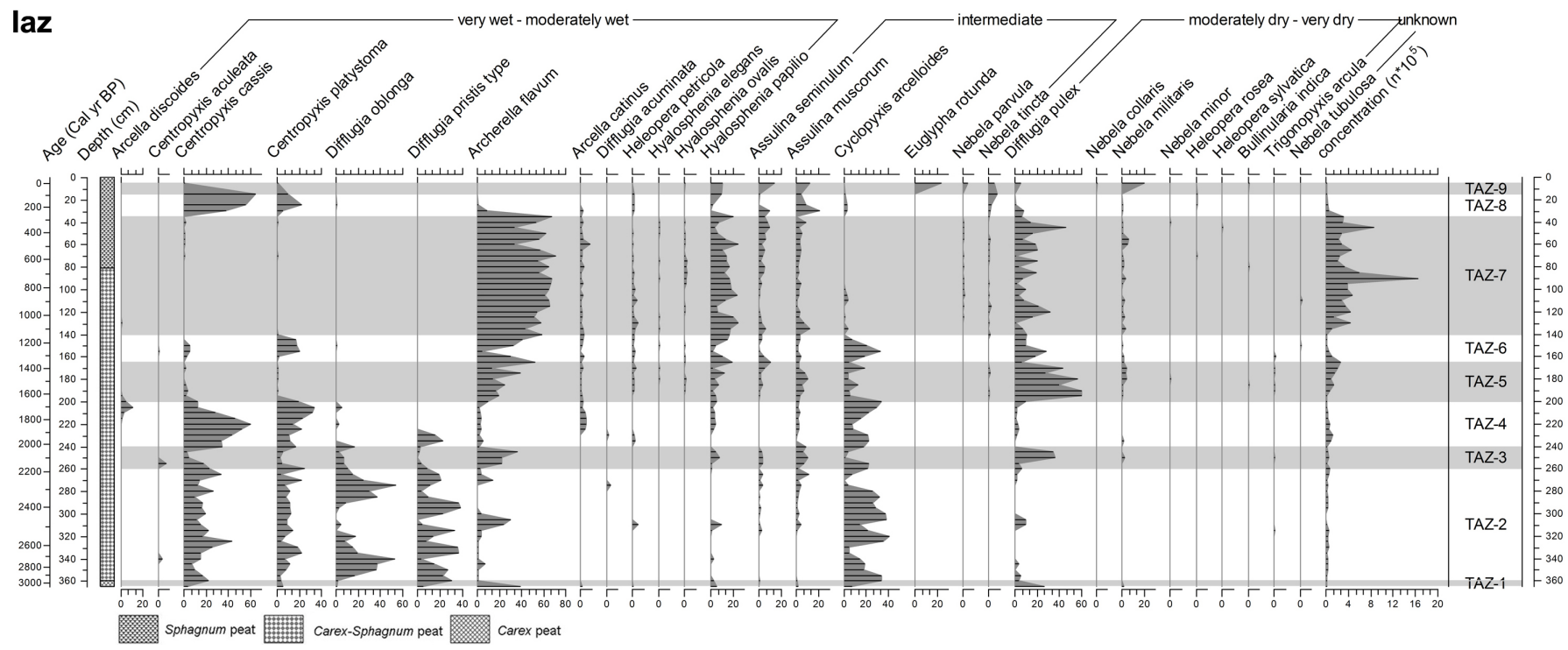

Fig. 3. Testate amoebae diagram representing the relative abundance of each taxa, lithology and the concentration of tests.

laz
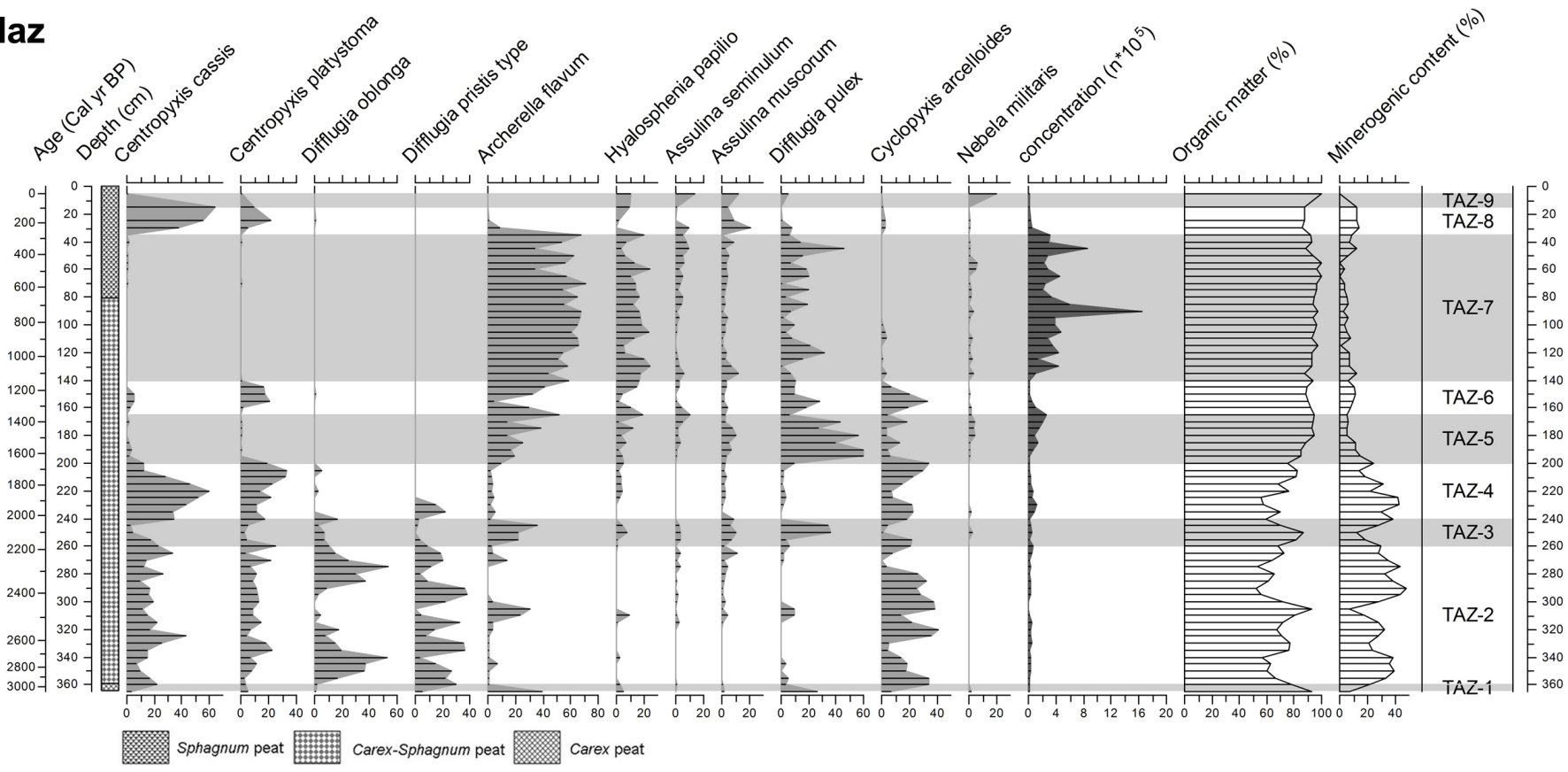

Fig. 4. Testate amoebae diagram with the dominant taxa, lithology, test concentration, OM (organic matter) and minerogenic material.

\section{Testate amoebae and LOI}

Based on the cluster analysis performed with the Past statistical program and the major changes of the fossil taxa domination, 9 distinct zones (TAZ 1-9) were identified.

TAZ 1 (3050 - 2950 cal yr BP)

Amphitrema flavum and Difflugia pulex were the dominant taxa for this zone, although they regress towards the end of the period. Centropyxis cassis, Difflugia pristis type, and
Cyclopyxis arcelloides were present with low percentages. The OM proportion was approximately $95 \%$ but decreased as the minerogenic material hits $25 \%$ towards the end of this period. In addition the test concentration was low.

TAZ 2 (2950 - 2200 cal yr BP)

The zone was dominated by Centropyxis cassis, Difflugia oblonga, Difflugia pristis type, and Cyclopyxis arcelloides. OM percentages fluctuated between $60-90 \%$ and the 
Table 1. $A M S^{14} C$ measurements and calibrated range age for the Iaz sequence (after Grindean et al., 2014).

\begin{tabular}{|c|c|c|c|c|}
\hline Depth (cm) & $\begin{array}{c}\text { Laboratory } \\
\text { number }\end{array}$ & ${ }^{14} \mathbf{C}$ yr BP & Cal. yr BP (2б) & $\begin{array}{c}\text { Data use to reconstruct } \\
\text { chronology (cal. yr BP) }\end{array}$ \\
\hline $12-14$ & Iaz I13 & $121.04 \pm 0.36$ & $44-153$ & 75 \\
\hline $132-134$ & Iaz I133 & $1150 \pm 30$ & $1004-1173$ & 1078 \\
\hline $212-214$ & Iaz I213 & $1805 \pm 30$ & $1673-1861$ & 1776 \\
\hline $282-284$ & Iaz I283 & $2520 \pm 35$ & $2064-2569$ & 2343 \\
\hline $342-344$ & Iaz I343 & $2395 \pm 35$ & $2530-3145$ & 2724 \\
\hline $442-444$ & Iaz I443 & $4090 \pm 35$ & $4627-4670$ & 4647 \\
\hline 450 & - & Pollen & - & 4800 \\
\hline 455 & - & Pollen & - & 4900 \\
\hline 490 & - & Pollen & - & 5700 \\
\hline 520 & - & Pollen & - & 7000 \\
\hline $532-534$ & Iaz I533 & $8380 \pm 50$ & - & Not used \\
\hline
\end{tabular}

minerogenic material between $10-40 \%$. Around 2900 cal yr BP a sharp increase in carbonates values correlates with the transition from a Carex peat to a Sphagnum-Carex peat. Test concentration of testate amoebae was low.

TAZ 3 (2200 - 2000 cal yr BP)

In this period the number of Amphitrema flavum, Hyalosphenia papilio, Assulina muscorum, and Difflugia pulex increased. OM concentration exceeded $85 \%$ and minerogenic material suddenly decreased. Test concentration remained at very low values.

\section{TAZ 4 (2000 - 1650 cal yr BP)}

Centropyxis cassis, C. platystoma, and Cyclopyxis arcelloides had a high abundance. Although part of the dominant species, Difflugia pristis type also disappeared towards the end of the period. In the first part of this zone OM reached percentages lower than $60 \%$ and the minerogenic material exceeded $40 \%$, whereas in the second part the OM had slightly recovered. Testate amoebae test concentration increased in the first part when the OM decreases.

\section{TAZ 5 (1650 - 1350 cal yr BP)}

This was an optimal period for Amphitrema flavum, Hyalosphenia papilio, Assulina seminulum, A. muscorum, Nebela militaris and Difflugia pulex that reached its highest number of individuals. OM had a stable accumulation of over $90 \%$ and the minerogenic material decreased to values lower than $10 \%$. Amoebae test concentration increased significantly. Around 1556 cal yr BP the peat type changed from a Sphagnum - Carex peat to a Sphagnum peat.

\section{TAZ 6 (1350 - 1150 cal yr BP)}

The previous species (from TAZ 5) had a decreased participation and increased abundance of Centropyxis cassis, C. platystoma, and Cyclopyxis arcelloides. OM slightly decreased with values still over $85 \%$ and the minerogenic material had slightly increased. Test concentration reached very low values abruptly.

\section{TAZ 7 (1150 - 280 cal yr BP)}

This was a period that represented the most stable environment for species like Amphitrema flavum, Hyalosphenia papilio, Assulina seminulum, A. muscorum, and Difflugia pulex. OM content and the minerogenic material had a similar trend as in the previous period. In this zone, the amoebae test concentration increased the most.

\section{TAZ 8 (280 - 100 cal yr BP)}

In this zone, the previous taxa (see TAZ 7) had a sudden drop in values and were replaced by Centropyxis cassis, $C$. platystoma, and Cyclopyxis arcelloides. OM slightly decreased to $85 \%$ and the minerogenic material increased at a maximum of $15 \%$. Testate amoebae concentration decreased suddenly to the minimum recorded values.

\section{TAZ 9 (100 - 0 cal yr BP)}

The most abundant taxa of this period were Hyalosphenia papilio, Assulina seminulum, A. muscorum, Difflugia pulex, and Nebela militaris. OM increased over $95 \%$ and the minerogenic material dropped to values less than 5\%. Test concentration of testate amoebae maintained low levels.

In the XY scatterplot diagrams (Fig. 5) five taxa were analyzed that hold the highest abundance along the peat core (Amphitrema flavum, Centropyxis cassis, C. platystoma, Difflugia pulex, and Hyalosphenia papilio). These taxa were compared with the organic matter and the minerogenic material fluctuations, however, the carbonates content was omitted as it had low concentrations and a relationship with the taxa could not be observed.

\section{DISCUSSIONS}

In the bottom part of the presented sequence $(3050-2950$ cal yr BP) the concentration of testate amoebae species are at their lowest values. This could be interpreted as a low preservation status of the environment. The period represents a moderately wet environment as suggested by the high concentration of Amphitrema flavum (40\%), taxon that in a modern ecology study from the Carpathian Basin prefers wet conditions (Schnitchen et al., 2006), and Difflugia pulex (20\%) which prefers rather dry conditions. This can be compared with the wet conditions from the dry-wet succession found in the Ştiucii Lake sequence (Feurdean et al., 2013) and Fenyvestető sequences (Schnitchen et al., 2006).

In the beginning of the period $2950-2200$ cal yr BP the TA assemblages changed. Centropyxis cassis, typically from 

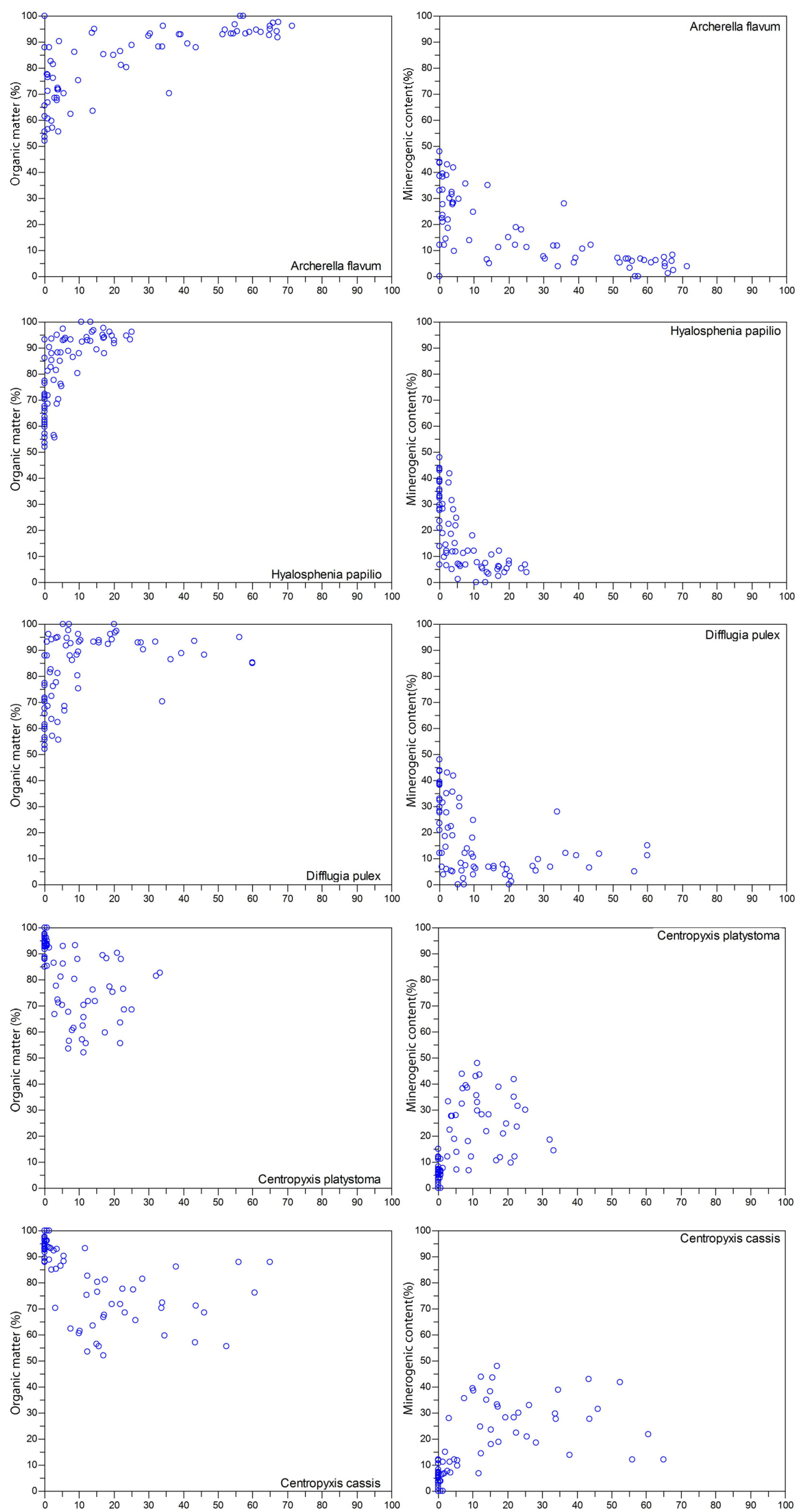

Fig. 5. Correlation between the dominant testate amoebae taxa and the value of organic matter (OM), and minerogenic material. 
a very wet substrate (Schnitchen et al., 2006; Tolonel, 1986), became dominant. In association with Difflugia pristis type, taxon that also prefers very wet environments (Charman et al., 2007), marks the beginning of a period with wet to very wet peat surface condition. Also in this time period, Cyclopyxis arcelloides appears with a high abundance. Described from variable conditions, from a moderate dry to a very wet soil (Warner, 1987), in this particular case is following the wet section of the dry-wet gradient. OM accumulation (over 90\%) also suggests a climate in which the peat surface vegetation reaches stable conditions. After the change in TA community, the peat surface humidity suffered high fluctuations between very wet and wet throughout the entire period. The TA assemblage was composed mainly of Centropyxis cassis, Difflugia pristis type, and Cyclopyxis arcelloides. Difflugia oblonga was more abundant, taxa found typically in very wet Sphagnum blanket (Charman et al., 2007). These fluctuating conditions are reflected in the minerogenic material as well, which on several occasions exceeded $40 \%$ of the material accumulated in the peat. As this accumulation of minerogenic material is in contrast with TA species characterizing wet conditions and a vegetation composed predominantly of Carex species (specific for minerotrophic mires), it can be interpreted as wet to very wet periods with high influx of humidity from outside of the mire. These fluctuations in the peat surface conditions could also be a reason for the poor test preservation reflected in the test concentration. In the same period, the surface vegetation changes from one dominated by Carex to one dominated by both Sphagnum and Carex. This could be correlated with the $2800-2400$ cal yr BP event described by Grindean et al. (2014) which imply an outward expansion of the hygrophilous forest belt and a widening of the inner swamp.

Between 2200 and 2000 cal yr BP the peat surface conditions have changed from very wet to moderately dry conditions. The species and their abundance found in this environment are similar with those found in the period 3050 - 2950 cal yr BP, exception being Assulina muscorum that increases in abundance. This is a wide spread taxon, generally found in greatest abundance during relatively dry conditions (Tolonen, 1986). This drier trend is in correlation with the microcharcoal analysis from Mlaştina de la Iaz peatland (Grindean et al., 2014) that shows a small increase in count, indicating a drier environment than the previous period. Dry conditions are described from the Molhaşu Mare site as well, where the microcharcoal analysis showed a dry environment between 2400 - 1800 cal yr BP (Feurdean and Wilis, 2008).

Between 2000 and 1650 cal yr BP, the peat surface conditions became again very wet and similar as in the period 2950 to 2200 cal yr BP were Centropyxis cassis, Centropyxis platystoma (taxa with very wet environmental requirements, similar to C. cassis and Cyclopyxis arcelloides) became dominant. This conditions can by correlated with the Ştiucii Lake sequence (Feurdean et al., 2013) in which wetter conditions between 2200 and 1800 cal yr BP and $1800-1600$ cal yr BP are suggested. The minerogenic material reached values over $40 \%$ marking once again a high input of humidity from outside of the mire.

Starting with 1650 Difflugia pulex (dry indicator) made up more than $60 \%$ of the TA communities. Among the wet indicators Amphitrema flavum and Hyalosphenia papilio were present with low values. This environment is in good correlation with the Fenyves-tetö sequence (Schnitchen et al., 2006) where the moderately dry conditions persist until year 370 BP. OM accumulation exceeds $90 \%$ starting a cycle with low input of material from outside of the mire. In Iaz peatland, these conditions were maintained until $1350 \mathrm{cal} \mathrm{yr}$ BP when Centropyxis platystoma and Cyclopyxis arcelloides taxa have increased in values indicating very wet peat surface conditions. These conditions were also reflected by the vegetation shifts (Grindean et al., 2014) that indicate possible flooding episodes between $1300-1100$ cal yr BP. Small concentrations of testate amoeba were found along this zone. These very wet conditions persisted until $1150 \mathrm{cal}$ yr BP, the beginning of a period where the wet indicators (Amphitrema flavum and Hyalosphenia papilio) dominated the TA fauna with more than $80 \%$ of the total taxa assemblage. This wet peat surface conditions lasted until yr $280 \mathrm{BP}$ and correlates with a gradually wetter conditions described in Tăul Muced profile between 1015 - 850 cal yr BP (Feurdean et al., 2015). The transition of the peatland surface vegetation from CarexSphagnum to predominately Sphagnum and the extremely low input of minerogenic material $(<5 \%)$ suggests an isolation of the peatland from the other water supplies except precipitation and could by related with the peatland transition from minerotrophic to ombrotrophic.

Between 280 and 100 cal yr BP, the high abundance of Centropyxis cassis and C. platystoma indicate a sudden episode with very wet peat surface conditions. Around $100 \mathrm{cal}$ yr BP dry climatic conditions are suggested by the presence of Difflugia pulex and Nebela militaris. A similar event was described at Tăul Muced by Feurdean et al. (2015).

The XY scatter plots correlation diagrams (Fig. 5) point out the correlation of Amphitrema flavum, Difflugia pulex, and Hyalosphenia papilio with a high OM content. Centropyxis cassis and $C$. platystoma have a low abundance compared to the increasing OM values (over the 90\%). In the case of the minerogenic material the situation is opposite: Centropyxis cassis and $C$. platystoma are abundant when accumulation rates exceed 10\%, while Amphitrema flavum, Difflugia pulex, and Hyalosphenia papilio are not abundant when the minerogenic material input is over $15 \%$. Because both $C$. cassis and $C$. platystoma have agglutinated tests, the correlation of their abundance with the minerogenic material could be explained by the fact that more mineral content favors the developing of agglutinated species.

\section{CONCLUSIONS}

The results from this study indicate that changes in moisture in peat bogs can be reconstructed based on the ecology and the distribution of testate amoeba assemblages.

Some rapid changes in the peatland surface conditions along the wet-dry gradient, as well as relatively stable climatic periods in the peat bog area were identified during the last 3050 years. These changes correlate well with other palaeoenvironmental records from Romania.

The LOI appears to show a relationship between the testate amoebae fauna and the $\mathrm{OM} /$ minerogenic material content. The relative abundances of very wet indicators or the agglutinated species increase when the minerogenic material input grows, while the wet-moderately wet indicators shows high 
abundance when OM content increases. During the periods with high OM concentration the peat bog could have been isolated from an external input of mineral nutrients, having an oligotrophic evolution.

These results demonstrate the utility and the importance of studying these organisms and their involvement in different studies as an additional proxy for the reconstruction of palaeohydrological changes in peat bogs during the Holocene.

Acknowledgment. RG acknowledges financial support from the Sectorial Operational Program for Human Resources Development 2007-2013, co-financed by the European Social Fund, under the project number POSDRU/159/1.5/S/132400 with the title „Young successful researchers-professional development in an international and interdisciplinary environment". IT received support from the Romanian National Authority for Scientific Research (UEFISCDI), project PN-II-PT-PCCA-2011-3.1-0924. Valuable suggestions from two anonymous reviewers and the editors are greatly appreciated.

\section{REFERENCES}

Amesbury, M.J., Mallon, G., Charman, D.J., Huges, P.D.M., Booth, R.K., Daley, T.J. \& Garneau, M. 2013, Statistical testing of a new testate amoeba-based transfer function for water-table depth reconstruction on ombrotrophic peat bogs in north-eastern Canada and Maine, United State. Journal of Quaternary Science, 28: 27-39. http://dx.doi.org/10.1002/jqs. 2584

Blaauw, M. 2010, Methods and code for 'classical' agemodelling of radiocarbon sequences. Quaternary Geochronology, 5: 512-518.

http://dx.doi.org/10.1016/j.quageo.2010.01.002

Booth, R.K., Zygmunt, J.R. 2005, Biogeography and comparative ecology of testate amoebae inhabiting Sphagnum-dominated peatlands in the Great Lakes and Rocky Mountain regions of north America. Diversity and Distribution, 11: 577-590.

http://dx.doi.org/10.1111/j.1366-9516.2005.00154.x

Charman, D.J., Warner, B.G. 1997, The ecology of testate amoebae (Protozoa: Rhizopoda) in oceanic peat bogs in Newfoundland, Canada: modeling hydrological relationship for palaeoenviramental reconstruction. Ecoscience, 4: 555-562.

Charman, D.J., Hendon, D. \& Woodland, W.A. 2000, The identification of testate amoebae (Protozoa: Rhizopoda) in Peats. Technical guide No. 9. Quaternary Research Association, London, 147 p.

Charman, D.J., Blundell, A. \& ACCROTELM Members 2007, A new European testate amoebae transfer function for palaeohydrological reconstruction on ombrotrophic peat bogs. Journal of Quaternary Science, 22: 209-221. http://dx.doi.org/10.1002/jqs.1026

Clarke, K.J. 2003, Guide to the identification of soil protozoatestate amoebae. Freshwater Biological Association, Ambleside, U.K., 40 p.

Dean, W.E. 1974, Determination of carbonate and organic matter in calcareous sediments and sedimentary rocks by loss on ignition: comparison with other methods. Journal of Sedimentary Research, 44: 242-248.
Fărcaş, S., de Beaulieu, J.L., Tanţău, I. \& Stoica, I.A. 2005, The absolute chronology aspects of the postglacial vegetation registered in the Căpăţâna peat bog, Apuseni Mountains. Studii şi cercetări (Biologie), Bistriţa, 10: 99-108.

Feurdean, A., Willis, K.J. 2008, The usefulness of a longterm perspective in assessing current forest conservation management in the Apuseni Natural Park, Romania. Forest Ecology and Management, 256: 421-430. http://dx.doi.org/10.1016/j.foreco.2008.04.050

Feurdean, A., Klotz, S., Mosbrugger, V. \& Wohlfarth, B. 2008, Pollen-based quantitative reconstructions of Holocene climate variability in NW Romania. Palaeogeography, Palaeoclimatology, Palaeoecology, 260: 494-504. http://dx.doi.org/10.1016/j.palaeo.2007.12.014

Feurdean, A., Liakka, J., Vanniere, B., Marinova, E., Hutchinson, S.M., Mossbruger, V. \& Hickler, T. 2013, 12,000 -Years of fire regime drivers in the lowlands of Transylvania (Central-Eastern Europe): a data-model approach. Quaternary Science Reviews, 81: 48-61. http://dx.doi.org/10.1016/j.quascirev.2013.09.014

Feurdean, A., Gałka, M., Kuske, E., Tanţău, I., Lamentowicz, M., Florescu, G., Liakka, J., Hutchinson, S.M., Mulch, A. \& Hickler, T. 2015, Last Millennium hydro-climate variability in Central-Eastern Europe (Northern Carpathians, Romania). The Holocene, 25 (7): 1179-1192. http://dx.doi.org/10.1177/0959683615580197

Grindean, R., Tanţău, I., Fărcaş, S. \& Panait, A. 2014, Middle to Late Holocene vegetation shifts in the NW Transylvanian lowlands (Romania). Studia UBB Geologia, 59 (1): 29-37. http://dx.doi.org/10.5038/1937-8602.59.1.2

Heiri, O., Latter, A.F. \& Lemcke, G. 2001, Loss on ignition as a method for estimating organic and carbonate content in sediments: reproducibility and comparability of results. Journal of Paleolimnology, 25: 101-110. http://dx.doi.org/10.1023/A:1008119611481

Hendon, D., Charman, D.J. 1997, The preparation of testate amoebae (Protozoa: Rhizopoda) samples from peat. The Holocene, 7: 199-205.

Institute of Biological Research 2012, Management Plan for the "Mlaștina de la Iaz" Natural Reservation.

http://www.mmediu.ro/beta/wp-content/uploads/2012/07/ 2012-07-27 legislatie planmanagementmlastinadelaiaz.pdf Juggins, S. 2003, C2 Version 1.5 User guide. Software for ecological and palaeoecological data analysis and visualization. Newcastle University, Newcastle upon Tyne, UK, 73 p.

Lamarre, A., Magnan, G., Garneau, M. \& Boucher, E. 2013, A testate amoeba-based transfer functions for paleohydrological reconstruction from boreal and subarctic peatlands in northeastern Canada. Quaternary international, 306: 88-96. http://dx.doi.org/10.1016/j.quaint.2013.05.054

Lamentowicz, M., Mitchell, A.D. 2005, The ecology of testate amoebae (Protists) in North-western Poland in relation to peatland ecology. Microbial Ecology, 50: 48-63. http://dx.doi.org/10.1007/s00248-004-0105-8

Lamentowicz, M., van der Knaap, W., Lamentowicz, Ł., van Leeuwen, J.F.N., Mirchell, E.A.D., Goslar, T. \& Kamenik, C. 2010, A near-annual palaeohydrological study based on testate amoebae from a sub-alpine mire: surface wetness and the role of climate during the instrumental period. Journal of Quaternary Science, 25 (2): 190-202.

http://dx.doi.org/10.1002/jqs.1295 
Lindberg, H. 1899, A rich peat deposit in Jorvis-parish Savo. Finska Mosskultur-Föreningens Årsbok 1899, 178-213, (in Swedish).

Mazei, Y., Tsyganov, A. 2006, Freshwater testate amoebae, Moscow: KMK.

Mitchell, E.A.D., van der Knaap, W.O., van Leeuwen, J.F.N. Buttler, A.J., Warner, B.G. \& Gobat, J.M. 2001, The palaeoecological history of the Praz - Rodet bog (Swiss Jura) based on pollen, plant macro-fossils and testate amoebae (Protozoa). The Holocene, 11 (1): 65-80. http://dx.doi.org/10.1191/095968301671777798

Munteanu, D., Raus, D.M. 1984, Documentaţii pentru crearea unor rezervaţii naturale de interes naţional în judeţul Sălaj. Acta Musei Porolissensis, 8: 300-314.

Opravilová, V., Hajek, M. 2006, The variation of testacean assemblages (Rhizopoda) along the complete base-richness gradient in fens: A case study from the Western Carpathians. Acta Protozoologica, 45: 191-204.

Ogden, C.G., Hedley, R.H. 1980, An atlas to freshwater testate amoebae. Oxford University Press, London, U.K., 222 p.

Payne, R.J. 2009, The standard preparation method for testate amoebae leads to selective loss of the smallest taxa. Quaternary Newsletter, 119: 16-20.

Payne, R.J., Mitchell, E.A. 2009, How many is enough? Determining optimal count for ecological and palaeoecological studies of testate amoebae. Journal of Paleolimnology, 42: 483-459. http://dx.doi.org/10.1007/s10933-008-9299-y

Payne, R.J., Kishaba, K., Blackford, J.J., \& Mitchell A.D. 2006, Ecology of testate amoebae (Protista) in Southcentral Alaska peatlands: building transfer function models for palaeoenvironmental studies. The Holocene, 16 (3): 403-414. http://dx.doi.org/10.1191/0959683606h1936rp

Reimer, P.J., Bard, E., Bayliss, A., Beck, J.W., Blackwell, P.G., Bronk Ramsey, C., Buck, C.E., Cheng, H., Edwards, R.L., Friedrich, M., Grootes, P.M., Guilderson, T.P., Haflidason, H., Hajdas, I., Hatté, C., Heaton, T.J., Hoffmann, D.L., Hogg, A.G., Hughen, K.A., Kaiser, K.F., Kromer, B., Manning, S.W., Niu, M., Reimer, R.W., Richards, D.A., Scott, E.M., Southon, J.R., Staff, R.A., Turney, C.S.M. \& van der Plicht, J., 2013, IntCal13 and Marine13 radiocarbon age calibration curves 0-50,000 years cal BP. Radiocarbon, 55 (4): 1869-1887. http://dx.doi.org/10.2458/azu js rc.55.16947

Schnitchen, C., Magyari, E., Tóthmérész, B., Grigorszky, J., \& Braun, M. 2003, Micropaleontological observations on a Sphagnum bog in East Carpathian region-testate amoebae (Rhizopoda: Testacea) and their potential use for reconstruction of micro-and macroclimatic changes. Hydrobiologia, 506-509: 44-49. http://dx.doi.org/10.1023/b:hydr.0000008553.82554.c2
Schnitchen, C., Charman, D.J., Magyari, E., Braun, M., Grigorszky, J., Tóthmérész, B., Molnar, M., \& Szántó, Zs. 2006, Reconstructing hydrological variability from testate amoebae analysis in Carpathian peat bogs. Journal of Paleolimnology, 36: 1-17. http://dx.doi.org/10.1007/s10933-006-0001-y

Stockmarr, J. 1971, Tablets with spores used in absolute pollen analysis. Pollen Spores, 13: 615-621.

Tanţău, I., Feurdean, A., de Beaulieu, J.L., Reille, M. \& Fărcaş, S. 2011, Holocene vegetation history in the upper forest belt of the Eastern Romanian Carpathians. Palaeogeography, Palaeoclimatology, Palaeoecology, 309: 281-290. http://dx.doi.org/10.1016/j.palaeo.2011.06.011

Tanţău, I., Feurdean, A., de Beaulieu, J.L., Reille, M. \& Fărcaş, S. 2014, Vegetation sensitivity to climate changes and human impact in the Harghita Mountains (Eastern Romanian Carpathians) over the past 15000 years. Journal of Quaternary Science 29: 141-152. http://dx.doi.org/10.1002/jqs.2688

Tolonen, K. 1986, Rhizopod analysis. In Handbook of Holocene palaeoecology and palaeohydrology (Berglund, B.E., Eds.). John Wiley, Chichester, p. 645-666.

Tolonen, K., Warner, B.G. \& Vasander, H. 1992, Ecology of testaceans (Protozoa: Rhizopoda) in mires in southern Finland: I. Autecology. Archiv für Protistenkunde, 142: 119-138. http://dx.doi.org/10.1016/S0003-9365(11)80076-X

Tolonen, K., Warner, B.G. \& Vasander, H. 1994, Ecology of testaceans (Protozoa: Rhizopoda) in mires in southern Finland: II. Multivariate analysis. Archiv für Protistenkunde, 144: 97-112.

http://dx.doi.org/10.1016/S0003-9365(11)80230-7

Warner, B.G. 1987, Abundance and diversity of testate amoebae (Rhizopoda: Testacea) in Sphagnum peat bogs in southwestern Ontario, Canada. Archiv für Protistenkunde, 133: 173-189.

http://dx.doi.org/10.1016/S0003-9365(87)80051-9

Warner, B.G., Charman, D.J. 1994, Holocene soil moisture changes on a peat bog in northwestern Ontario based on fossil testate amoebae (Protozoa) analysis. Boreas, 23: 270-279. http://dx.doi.org/10.1111/j.1502-3885.1994.tb00949.x

Wall, A., Gilbert, D., Magny, M., \& Michell, E.A.D. 2009, Testate amoebae analysis of lake sediments: impact of filter size and total count on estimates of density, diversity and community structure. Journal of Paleolimnology, 43: 689-704. http://dx.doi.org/10.1007/s10933-009-9360-5

Woodland, W.A., Charman, D.J., \& Sims, P.C. 1998, Quantitative estimates of water tables and soil moisture in Holocene peat bogs from testate amoebae. The Holocene, 8: 261-273. http://dx.doi.org/10.1191/095968398667004497 